\title{
Human rights and the right to abortion in Latin America
}

\author{
Direitos humanos e direito ao aborto na América Latina
}

Alejandra Zúñiga-Fajuri ${ }^{1}$

${ }^{1}$ Escuela de Derecho, Universidad de Valparaíso. Errázuriz 1834, Quinta Región de Valparaíso. 800 $242800 y ́$ Valparaíso Valparaíso Chile. alejandra.zuniga@uv.cl
Abstract The scope of this study is to question the fact that in some countries in Latin America (Chile, El Salvador, Nicaragua, Honduras and the Dominican Republic) abortion is still forbidden in all situations. Even after all the debate on this thorny issue, the theory of human rights is not often used in the defense of abortion. This is clearly related to the pervasive, albeit unspoken belief that, due to their condition, pregnant women inherently lose their full human rights and should surrender and even give up their lives in favor of the unborn child. This article seeks to show that an adequate reading of the theory of human rights should include abortion rights through the first two trimesters of pregnancy, based on the fact that basic liberties can only be limited for the sake of liberty itself. It also seeks to respond to those who maintain that the abortion issue cannot be resolved since the exact point in the development of the embryo that distinguishes legitimate from illegitimate abortion cannot be determined. There are strong moral and scientific arguments for an approach capable of reducing uncertainty and establishing the basis for criminal law reforms that focus on the moral importance of trimester laws.

Key words Abortion, Human rights, Health care
Resumo O objetivo deste estudo é questionar o fato de alguns países da América Latina (Chile, El Salvador, Nicarágua, Honduras e República Dominicana) proibirem o aborto em qualquer situação. Mesmo após todos os debates sobre o tema, poucas vezes é utilizada a teoria dos direitos humanos para sua defesa. O que certamente está relacionado com a crença generalizada, embora velada, de que as mulheres grávidas perdem, devido a esta condição, seus direitos humanos, devendo ceder e até renunciar à sua vida em favor do nascituro. Este artigo pretende demonstrar que uma leitura adequada da teoria dos direitos humanos deve incluir o direito ao aborto nos três primeiros meses de gravidez, baseado em que as liberdades fundamentais só podem ser limitadas pelo bem da própria liberdade. Também tem a intenção de responder aos que sustentam que o tema aborto não pode ser resolvido já que o ponto exato no desenvolvimento embrionário separando o feito da forma legítima do da ilegítima não pode ser determinado. Existem argumentos morais e científicos consistentes para reduzir a incerteza e assentar as bases para reformas penais centradas na importância moral dos prazos.

Palavras-chave Aborto, Direitos Humanos, Cuidado sanitário 


\section{Introduction}

An adequate reading of general human rights theory should include abortion rights through the first two trimesters of pregnancy, noting, with Rawls, that basic liberties can only be limited for the sake of liberty itself ${ }^{1}$. This paper intends to respond to those who claim that the abortion issue cannot be resolved, since the exact point in embryonic development that separates legitimate and illegitimate abortion cannot be determined. Potent moral arguments exist for an approach capable of reducing uncertainty and establishing a basis for reforms that move past prescriptive laws and focus on the moral importance of trimester laws.

\section{The World's Greatest Health Inequity}

Chile, El Salvador, Nicaragua, Honduras and Republica Dominicana criminalize all sorts of abortion, even in case of rape or when the woman's life or health is at risk. To the Committee against Torture, these laws are an act of torture that flouts women's basic human rights. The CAT made clear that Chile's policy of delaying treatment to coerce confessions from women seeking "life saving treatment in public hospitals after illegal abortions, denying them confidential treatment, or using their statements against them in a proceeding constitute a contravention of the Torture Convention"2.

In human terms, making abortion illegal is a very costly way to allocate scarce resources. "The question is not whether we agree with abortion. Legal or not, statistics show that women will have abortions. The choice is between the life or death of these women. Keeping punitive abortion laws in place means opting for death" ${ }^{3}$. Criminalizing abortion does not lower the numbers and has been proven completely ineffective policy. In South America alone, each year about 30 per 1,000 women between the ages of 15 and 45 will have an abortion. In the Netherlands, where abortion is legal, the figure is 8 per 1,000 . In addition, punitive laws single out poor women. Where abortion is legal, the risk of death is less than 1 per 500,000 women, making abortions safer than treatment with penicillin and just about any other type of medical procedure ${ }^{4}$.

Punitive laws force women to choose between an unsafe abortion and enforced maternity. These laws not only disallow behavior, they forcibly impose maternity. But as Ferrajoli notes "The abortion ban and resulting coercive maternity impose not so much an obligation not to abort, but a life upheaval of incalculable consequences. Women forced into pregnancy and childbirth will have to forego many life objectives to raise that child, thus entering into servitude of sorts" ${ }^{\text {. }}$

\section{Abortion and Human Rights in Latin America}

Therapeutic abortions are legal everywhere in the western hemisphere except Chile, El Salvador, Nicaragua, Honduras and Republica Dominicana (During the Pinochet government, all forms of abortion are judged as felonies and punishable with prison. However, women still get abortions which make Chile the country in Latin America with the highest abortion rates, proportionally) ${ }^{6}$. In all these countries Catholic Church typically argues that aborting is killing a human being, and that killing a human being goes against God's moral code. This argument forgets that, ever since the $18^{\text {th }}$ century, political theorists and philosophers have argued that human rights are subjective rights granting entitlements that can only be curtailed to protect others. As such, human rights cannot be restricted or overridden on behalf of collective, utilitarian or consequentialist interests or abstract values such as the concepts of "human life" and "potential human life" advanced by religious or ideological groups, even if upheld by a majority. In addition, determination of the moral legitimacy and legality of abortion requires, as a counterweight to women's human rights, identifying the rights accruing to the embryo or fetus as a person or at least as a separate being with a protected legal interest (not as a value).

The notion of human rights also requires parsing the semantic units involved. The term "human" is the sole relevant criterion for entitlement. While the term "right" has many definitions, it refers here to the entitlements or prerogatives accruing to an individual. This apparently simple formulation, however, begs the question: What does it mean to be entitled to rights? Or to be a human being?7. The term "human" implies that the sole standard a holder must meet is membership in a class of individuals known as human beings; i.e., human rights are moral rights enjoyed by dint of personhood. Does that mean that belonging to the human species is the sole factual condition of relevance? Defining "human" in terms of basic organic properties, such as chromosome structure, of necessity assumes that all are equally entitled to such rights. But as C. Nino 
notes, it is not obvious that biological traits alone, disconnected as they are from the moral content of rights, can be the sole grounds for granting a right. Such an assumption would involve a crude sort of 'speciesism' akin to racism (not to mention that persons with Down syndrome carry an extra chromosome. Also, Hume's principle logically prevents the inference of prescriptions, such as the duty to grant a right, from mere descriptions, such as biological traits. As Singer notes, rather than biology (or any other kind of descriptive theory), moral citizenship is a question of moral theory in the broad sense ${ }^{8}$.

Human beings can also be described on the basis of morally relevant traits. As Kant noted, these include rationality and the capacity to strive for ends. Or as Rawls writes, the capacity to have a sense of justice and a concept of good ${ }^{1}$. Although such a stand might lead to the unpleasant conclusion that some members of the species do not belong in the human class, human rights should then be the moral rights enjoyed by all independent holders of interests capable of self-awareness and of adjusting their lives to their own value judgements. The class of beings alluded to in this description includes all moral persons. A contingent but not necessary fact is that this class is made up of beings who are biologically human.

Human rights can also be described from an analytical point of view. Human rights are said to be intrinsic, universal, overarching and absolute. As moral requirements, their strength lies in being the materialization of interests of particular relevance to all. They are absolute in that they supersede any and all other moral requirements and are to be upheld regardless. Human rights are prima facie rights in that, as a matter of principle, they cannot be suppressed and can only be limited by the rights of others. Another crucial point is that human rights are individual, not aggregative. Outside the human class, no other individually considered being is entitled. As such, no one -not a majority, nor the State, the common good or any other similar construct has concurrent rights morally justifying suppression. This includes religious or metaphysical constructs such as the sanctity of human life or the potential human life. Human rights are counter-majority rights that set a threshold and trump collective social goals ${ }^{9}$. A right that can be stifled every time ignorance of it is said to yield a socially valuable result is not a true right -it is a flimsy concession made for the sake of the collective interest. Human rights are strong rights in that they admit no limit founded on social or common goals, however desirable. Taking women's human rights seriously requires disallowing the abstract need to uphold the sanctity of human life, the grounds used by courts and legislations to criminalize abortion. Consistent with this conception, limiting women's rights would require determining if the unborn has the features generally ascribed to human beings, or if at any stage of its development it displays features warranting recognition of rights.

\section{Embryos, Fetuses and Persons}

Notwithstanding the above, regarding a fetus as a member of the human class in the sense of a moral person remains a difficult proposition, as the often overlapping notions of legal and moral personhood must be reconciled. The former does not inspire a great deal of debate. Most jurisdictions concur that only born individuals are persons for the purposes of entitlement to subjective rights. And Chile is not an exception. But is a fetus a moral person?

Rawls looked into the concept from the standpoint of Kant's theory of autonomous and ethical behavior. To Rawls, the requirements to be regarded as a person are more stringent than having been born. Moral persons are those capable of a sense of justice and a certain concept of good. The former requires the ability to understand, apply and act per the public concept of justice that defines the equitable terms of social cooperation. The latter requires the capacity to embrace a certain concept of good, "an ordered family of final ends and aims which specifies a person's conception of what is of value in human life" ${ }^{\prime 10}$. As Rawls further notes, only those who act with justice are entitled to justice. Regarding the fetus as a moral person does not seem possible, as newborns or the mentally disabled, for example, would not meet the standard of personhood set by the Kantian ideal of moral autonomy.

The above is of crucial importance to regulating abortion. First, it requires accepting that since no one else, whether a legal or moral person, can assert rights, there is no reason whatsoever to limit or suppress the human rights of women. Human rights are overarching and individual and can only be curtailed for the sake of others. No value or being other than 'an individually considered moral person' can assert such rights. This does not entail the nonexistence of arguments for regulating and even restricting abortion; it means that doing so requires ascertaining how to identify in an individually consid- 
ered fetus, at its various stages of growth, the moral features shared by all that warrant attributing rights to it. In other words, ascertaining when the fetus acquires a relevant interest worthy of protection and capable of overriding a woman's fundamental right to reproductive autonomy. Two possible moments exist: When the fetus acquires perception and awareness of pain or when it becomes viable outside the womb.

The problem with the viability approach used, inter alia, by the U.S. Supreme Court to decriminalize abortion in 1973, with Roe vs. Wade, is that medical science keeps pushing viability forward, currently to about 24 weeks of gestational age. As such, new advances could further restrict women's rights. In other words, the viability standard is arbitrary, as it hinges on factors, such as the state of the technique in any given country, that fluctuate over time and space ${ }^{8}$. That said, Ruiz Miguel asserts that such an objection does not suffice, as there are many fields in which scientific progress alters assessment criteria without necessarily making them arbitrary: "The sole decisive critique of viability is that, on its own, dependence does not suffice to freely dispose of the life of an admittedly separate being." ${ }^{.1}$. But as noted above, being a separate, viable being does not a holder of human rights make, since such a being does not in principle possess the features required for membership in 'the human class'.

As such, it would seem preferable to ponder whether it is possible for the fetus, even if not a moral person, to independently possess a legally protected interest. Indeed, the difference between early- and late-term abortion lies at the heart of the abortion law reforms adopted throughout Europe. As Valdés notes, "The moral obligation owed a born person is not the same as that owed a fertilized egg. A fertilized egg cannot be hurt, because it lacks the capacity to feel. In addition, it is hard to thwart the desires, personal interests or life objectives of a fertilized egg, simply because it has none"12. Fertilized eggs differ from a person precisely in the areas that matter the most to moral issues - i.e., pain, desires, interests.

In addition, science has shown human development to be a gradual process. After several days, a fertilized egg is still only a tiny cluster of cells without a single anatomical feature of the human being it will later become. Up to about fourteen days after fertilization, we cannot even tell if the embryo is going to be one or two individuals. Is there no morally significant boundary between a fertilized egg and a child? Those normally cited i.e., birth, viability, motion- do not seem perti- nent. What seems important is the capacity of the fetus to experience pain or be aware of suffering. Singer writes that if the fetus is capable of feeling pain, then "the interests of the fetus in not suffering should be taken into account in the same way that we should take into account the interests of sentient, but not self-conscious, nonhuman animals"8. Dworkin takes issue with the notion that the fetus has interests of its own, in particular the interest not to be destroyed following fertiliza$\operatorname{tion}^{13}$. A fetus capable of experiencing pain might be said to have an interest. Inflicting pain on a fetus endowed with a nervous system sufficiently developed to experience it is highly unfavorable to its interests. But a fetus is not aware of pain until the end of pregnancy, since until then its brain is not sufficiently developed.

Recent research shows that fetuses only become capable of experiencing pain at 29 to 30 weeks, as the brain structures that recognize noxious stimuli are among the last to form. Pain travels through the nervous system, and the more specialized cerebral cortex is last to form. "Pain perception requires conscious recognition or awareness of a noxious stimulus. Neither withdrawal reflexes nor hormonal stress responses to invasive procedures prove the existence of fetal pain, because they can be elicited by nonpainful stimuli and occur without conscious cortical processing. Fetal awareness of noxious stimuli requires functional thalamocortical connections. Thalamocortical fibers begin appearing between 23 to 30 weeks' gestational age, while electroencephalography suggests the capacity for functional pain perception in preterm neonates probably does not exist before 29 or 30 weeks ${ }^{14-16}$.

Scientific knowledge about the human genome, fertilization, development of the human embryo and the physiology of pregnancy shows that a 12-week embryo is not a biological individual, much less a person, because: (a) It lacks the ability to live unaided outside the womb; (b) Accepting that possession of the complete human genome makes a 12-week embryo a person would require accepting that all cells or organs in the adult organism, which also possess the complete human genome, are persons. As such, removal of an organ would be akin to killing billions of persons; (c) At 12 weeks, brain development is in its initial stages. The cerebral cortex and neural connections required for experiencing sensations have not yet formed; (d) As such, a 12-week embryo is incapable of experiencing pain or of any other sensory perception, let alone suffer or enjoy ${ }^{17}$. 
Scientific evidence seems to have provided a leading basis for abortion law reforms adopted across developed countries. It seems both reasonable and consistent with human rights theory that if restriction of rights needs to be justified on the basis of the "person-person" dualism, the law should limit abortion only when some of the relevant features shared by all humans, notably perception and awareness of pain, are present in the fetus. This is apparent in the 12-week legal limit employed by most of Europe. Cyprus allows 28 weeks under certain circumstances, followed by Finland, the United Kingdom and the Netherlands with 24 weeks. Other countries allow from 12 to 22 weeks. In the United States, abortion bans through the first two trimesters of pregnancy have been ruled unconstitutional.

\section{Conclusion}

Although most people are demanding some change in the abortion status quo, politicians don't appear to be listening. And the reason is that the interpretations of the conflict between constitutional recognition of rights, including women's rights, and laws on the status of the embryo, is not consistent with the principle that individuals are ends in themselves, not means that can be sacrificed or used to some other end. Laws that criminalize all abortion entail the complete preeminence of one of the legal interests at stake and the absolute sacrifice of the pregnant woman's fundamental rights, violating her dignity by reducing her to a mere receptacle for the fetus, without rights or interests of constitutional relevance worthy of protection. Women cannot be forced to act heroically and lawmakers cannot regard human beings with full dignity as mere vehicles for the reproduction of the species. No one, in no other situation, is compelled to perform the supererogatory acts required of pregnant women.

Over the past thirty years, science has confirmed that sensory capacities warranting legal consideration only appear in the last stages of pregnancy. As such, abortion should be decriminalized in all cases considered critical under human rights standards, including rape and danger to life and health. Furthermore, punitive laws should be superseded by legislation that gives due moral consideration to the various stages of intrauterine life and recognizes that pregnancy should not strip women of their rights, freedoms, or dignity. 


\section{Referências}

1. Rawls J. A Theory of Justice. Harvard: Harvard University Press; 1971.

2. United Nations (UN). Committee Against Torture (CAT). Concluding Observations, Chile. U.N. Doc. CAT/C/CR/32/5, Jun. 14. Geneva: UN; 2004.

3. De la Barreda S. The crime of abortion, a mask of good conscience. Ciudad de México: Instituto Nacional de Estudios Criminales; 1991.

4. World Health Organization (WHO). Unsafe abortion in 2008: global and regional levels and trends. Washington: WHO; 2008.

5. Ferrajoli L. The question of the embryo: between law and morality. Jueces para la democracia, información y debate 2002; 44.

6. Requena M. Induced abortion in Chile. Santiago: Sociedad Chilena de Salud Pública; 1990.

7. Nino CS. The Ethics of Human Rights. Oxford: Oxford University Press; 1991.

8. Singer P. Practical Ethics. Cambridge: Cambridge University Press; 1993.

9. Dworkin R. Taking Rights Seriously. Cambridge: Harvard University Press; 1977.

10. Rawls J. Justice as Fairness: A Restatement. Cambridge MA: Belknap Press; 2001.

11. Ruiz Miguel A. Abortion: Constitutional problems. Madrid: Centro de Estudios Constitucionales; 1990.

12. Valdés R. The problem of abortion. In: Vásquez R, editor. Bioética y Derecho, fundamentos y problemas actuales. México: Fondo de Cultura Económica; 1999.

13. Dworkin R. Life's Dominion: An Argument About Abortion, Euthanasia, and Individual Freedom. New York: Alfred A. Knopf; 1993.

14. Lee SJ, Ralston HJ, Drey EA, Partridge JC, Rosen MA. Fetal Pain: A Systematic Multidisciplinary Review of the Evidence. JAMA 2005; 294(8):947-954.

15. Fitzgerald M. Neurobiology of fetal and neonatal pain. In: Wall P, Melzack R, editors. Textbook of pain. Edinburgh: Churchill Livingstone; 1994.

16. Derbyshire SW, Furedi A. Fetal pain is a misnomer. BMJ 1996; 313(7060):795.

17. Report of the College of Bioethics of Mexico. Rev Proceso. Semanario de información y análisis 2007; 1590(April):8 .

Artigo apresentado em 09/05/2013

Aprovado em 25/06/2012

Versão final apresentada em 04/07/2013 